\title{
Cell Fate Determination and the Switch from Diffuse Growth to Planar Polarity in Arabidopsis Root Epidermal Cells
}

\author{
Daria Balcerowicz ${ }^{\dagger}$, Sébastjen Schoenaers ${ }^{\dagger}$ and Kris Vissenberg * \\ Integrated Molecular Plant Physiology Research, Department Biology, University of Antwerp, Antwerpen, Belgium
}

OPEN ACCESS

Edited by:

Frantisek Baluska,

University of Bonn, Germany

Reviewed by:

Rishi Bhalerao,

Sveriges Lantbruksuniversitet,

Sweden

Myeong Min Lee,

Yonsei University, South Korea

Su-Hwan Kwak,

Long Island University, USA

*Correspondence:

Kris Vissenberg

kris.vissenberg@uantwerp.be

${ }^{t}$ These authors have contributed

equally to this work.

Specialty section:

This article was submitted to Plant Evolution and Development, a section of the journal

Frontiers in Plant Science

Received: 28 October 2015 Accepted: 07 December 2015 Published: 23 December 2015

Citation:

Balcerowicz D, Schoenaers S and Vissenberg K (2015) Cell Fate Determination and the Switch from

Diffuse Growth to Planar Polarity in Arabidopsis Root Epidermal Cells.

Front. Plant Sci. 6:1163.

doi: 10.3389/fpls.2015.01163
Plant roots fulfill important functions as they serve in water and nutrient uptake, provide anchorage of the plant body in the soil and in some species form the site of symbiotic interactions with soil-living biota. Root hairs, tubular-shaped outgrowths of specific epidermal cells, significantly increase the root's surface area and aid in these processes. In this review we focus on the molecular mechanisms that determine the hair and non-hair cell fate of epidermal cells and that define the site on the epidermal cell where the root hair will be initiated (=planar polarity determination). In the model plant Arabidopsis, trichoblast and atrichoblast cell fate results from intra- and intercellular position-dependent signaling and from complex feedback loops that ultimately regulate GL2 expressing and non-expressing cells. When epidermal cells reach the end of the root expansion zone, root hair promoting transcription factors dictate the establishment of polarity within epidermal cells followed by the selection of the root hair initiation site at the more basal part of the trichoblast. Molecular players in the abovementioned processes as well as the role of phytohormones are discussed, and open areas for future experiments are identified.

Keywords: Arabidopsis thaliana, root differentiation, root hair development, initiation, planar polarity, cell fate determination, auxin

\section{THE Arabidopsis ROOT AND ITS DEVELOPMENTAL ZONES}

Plant roots fulfill important functions and help to maximize survival and adaptation of plants to continuously changing environments. They serve in water and nutrient uptake, provide anchorage of the plant body in the soil and in some species form the site of symbiotic interactions with soilliving biota. The root body consists of many different cell types that all originate from the meristem and that all pass through consecutive phases of cellular activities before developing specialized functions and reaching maturity. The meristematic, transition, elongation, and differentiation zone of individual roots can be well defined based on their characteristic cellular activities (Verbelen et al., 2006; Figure 1). In the meristematic zone cells undergo mitotic divisions. As such, this zone mainly determines the root's cell number. Upon leaving the meristem, cells modulate their physiological state and architecture to prepare for rapid elongation: they progressively develop a central vacuole, polarize their cytoskeleton and remodel their cell walls. Parallel deposition of cellulose microfibrils, transverse to the future long axis of the cell creates anisotropic cell wall mechanics that accommodate longitudinal cell expansion (Anderson et al., 2010). 
This highly ordered cellulose deposition by cellulose synthase enzymes is guided by cortical microtubules and related POMPOM2/Cellulose Synthase Interacting1 (CSI1) proteins (Paredez et al., 2006; Bringmann et al., 2012a,b). In the adjacent fast elongation zone, anisotropic diffuse growth, characterized by expansion of the entire cell's surface, results in a massive increase in the cell's volume. This process is accompanied by drastic and specific cell wall alterations, including changes in the transcription of peroxidases [which produce the reactive oxygen species (ROS) needed for cell expansion], xyloglucan endo-transglycosylase/hydrolases (XTHs) that play a role in breaking and re-joining xyloglucan cross-bridges between cellulose microfibrils, thereby weakening the cell wall (Van Sandt et al., 2007; Wilson et al., 2015) and cell wall loosening expansins (Cosgrove, 2000). Anderson et al. (2010) suggest that while the cell elongates, previously deposited cellulose fibrils reorient toward a longitudinal orientation, which might provide additional tensile strength in that dimension. In combination with rigidification of other cell wall components and changes in the protein composition, this could eventually limit longitudinal expansion so that the growth rate declines at the end of the fast elongation zone before being reduced to zero in the differentiation zone. Although epidermal wall architecture and proteins have just restrained cellular expansion in this developmental zone, root hairs yet emerge at well-defined spots of specific epidermal cells. These long, tubular-shaped outgrowths significantly increase the root's surface area and aid in water and nutrient absorption (Keyes et al., 2013). Arabidopsis root hairs gained scientific attention as they represent

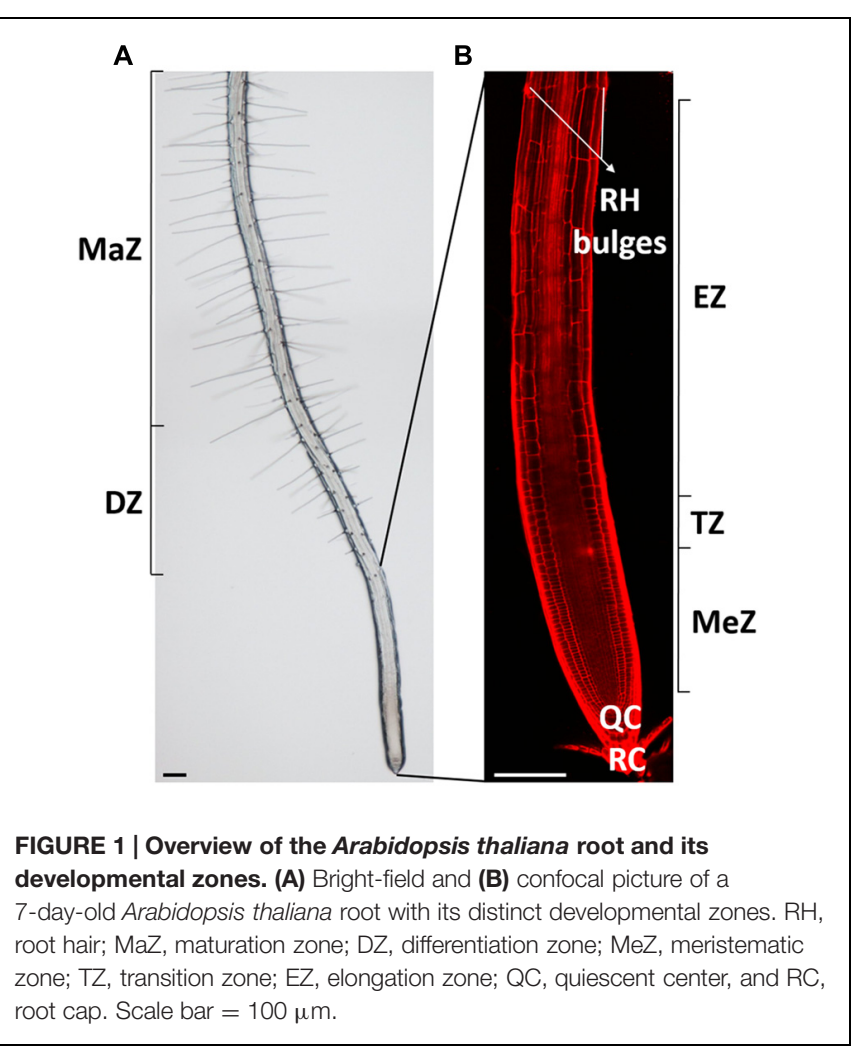

an attractive model for studying plant cell growth and its regulation.

In the remainder of the review we will try to address the questions (1) how epidermal cells know whether or not to initiate a root hair, (2) how the position of the root hair bulge is defined, and (3) which mechanisms are required to form the actual bulge. We will further identify future challenges to even better understand the mechanism and control of root hair development.

\section{DEFINITION OF ROOT HAIR CELL FATE}

All cells that arise from the meristem go through the elongation zone before entering the differentiation zone. How do epidermal cells that all pass through the same developmental zones, perform similar functions, and initially look morphologically similar (despite some subtle differences, see later) gain a different cell fate?

In Arabidopsis the root epidermis is arranged in clearly distinguishable cell files arising from 16 initial cells. Upon maturation the epidermis consists of two distinct cell types: root hair cells (trichoblasts) and non-hair cells (atrichoblasts) (Dolan et al., 1993). The identity of epidermal cells is highly regulated by a position-dependent mechanism as cells that lie above the junction of two cortical cells ("H" position) produce root hairs, while cells that make contact with only one cortical cell ("N" position) remain hairless. Since the cortex is a ring of eight cells, the trichoblasts are always arranged into eight files and trichoblast cell files rarely directly neighbor each other (Dolan et al., 1994; Figure 2A).

The patterning of both epidermal cell types is first established during the early stages of embryogenesis, which is far before the first signs of epidermal differentiation. The expression of GLABRA2, a transcription factor required for specification of the atrichoblast cell fate, can already be detected in the heart stage embryo (Lin and Schiefelbein, 2001). In addition to genetic pathway differences, a cellular dimorphism between trichoblasts and atrichoblasts already exists in the meristematic zone, long before actual root hair formation (Dolan et al., 1994): root hair cells are shorter (Dolan et al., 1994) and less vacuolated (Galway et al., 1994), they have a denser cytoplasm (Dolan et al., 1994) and display a higher cell division rate (Berger et al., 1998).

Several genes that regulate cell fate determination and cause these subtle differences have been described (Figure 2B). Many studies suggest that the root hair cell fate depends on the absence of an inhibitory pathway that prevents differentiation into a hair cell (Wada et al., 1997; Lee and Schiefelbein, 1999). One of the key components in this network is TRANSPARENT TESTA GLABRA (TTG1), which encodes a small protein with WD40 repeats involved in creating protein-protein interactions (Walker et al., 1999). TTG1 forms a complex with the basic HelixLoop-Helix (bHLH) transcription factors GLABRA3 (GL3) and ENHANCER OF GLABRA3 (EGL3) (Payne et al., 2000; Esch et al., 2003; Zhang et al., 2003). As loss-of-function mutations in each of these genes result in excessive trichoblast production, they were found to inhibit the root hair cell fate 
A

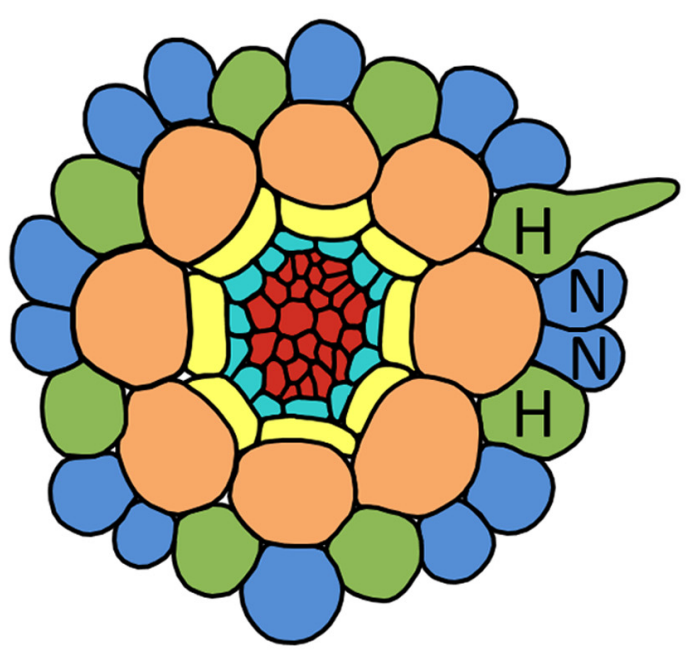

प Epidermis

$\square$ Cortex

$\square$ Endodermis

$\square$ Pericycle

$\square$ Vascular tissue

B

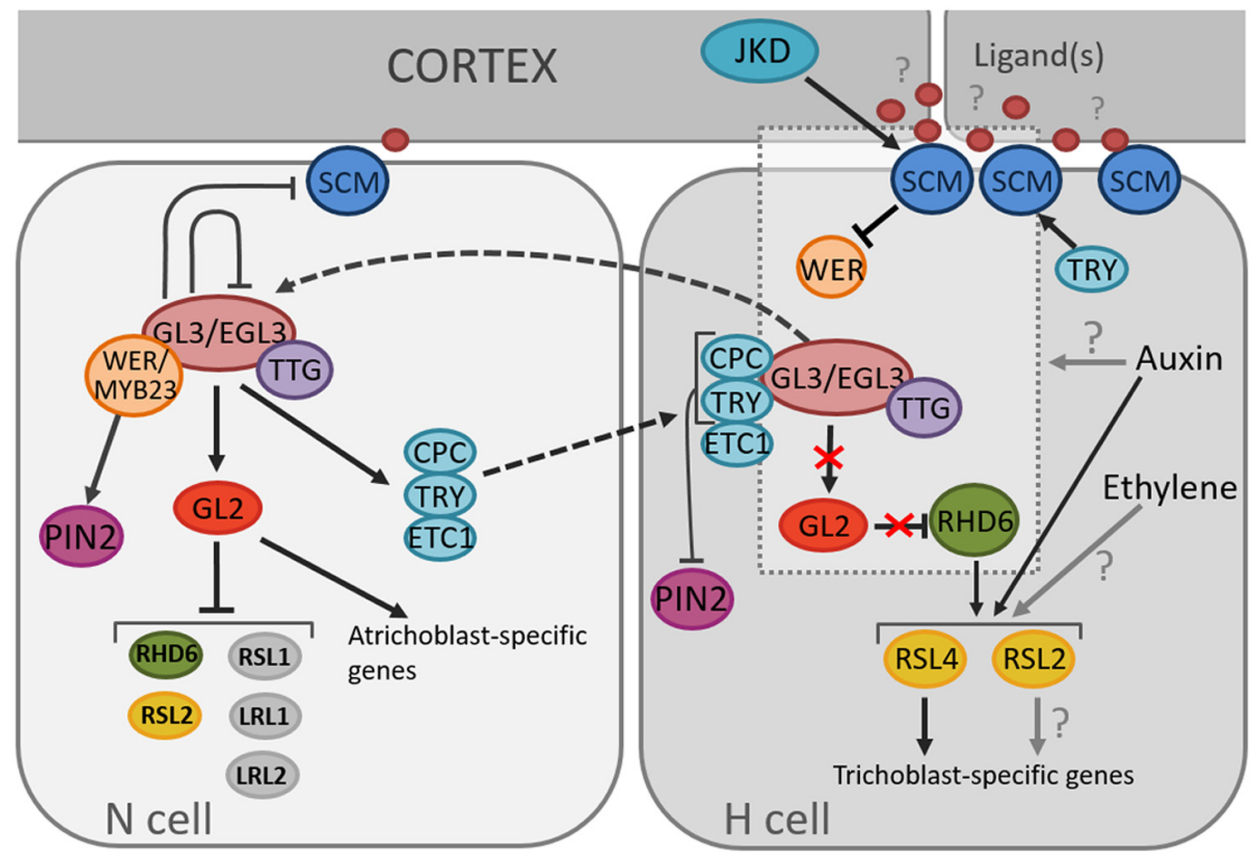

FIGURE 2 | Cellular organization of the Arabidopsis root and model for the position-dependent cell fate determination. (A) Schematic representation of the cellular organization on a transverse section through the Arabidopsis root depicting the position of root hair $(\mathrm{H})$ and non-root hair $(\mathrm{N})$ cells. (B) Model of molecular pathways determining root hair and non-root hair cell fate in the Arabidopsis epidermis. Arrows, blunted lines and broken lines are indicative of positive control,

negative regulation, and intra/intercellular protein movement, respectively.

(Galway et al., 1994; Bernhardt et al., 2003; Zhang et al., 2003).

The activity of the GL3/EGL3/TTG1 complex depends on the relative abundance of two MYB transcription factors, WEREWOLF (WER) and CAPRICE (CPC) that act in opposition to each other (Wada et al., 1997; Lee and Schiefelbein, 1999). It is proposed that the specific epidermal cell fate is a consequence of WER activity being concentrated in the cells in the future $\mathrm{N}$ position, whereas CPC activity is present only in cells in the future $\mathrm{H}$ position (Schiefelbein, 2000). When the WER protein binds to TTG1/GL3/EGL3, the root hair-inhibitory complex becomes active and promotes the expression of homeodomain transcription factor GLABRA2 (GL2) (Rerie et al., 1994; Lee and Schiefelbein, 1999). In addition, GL2 transcription was shown to also depend on HDA6-mediated histone deacethylation (Li et al., 2015). GL2 in turn inhibits transcription of the bHLH transcription factor ROOT HAIR DEFECTIVE 6 (RHD6) (Masucci and Schiefelbein, 1994; Menand et al., 2007), which leads to the expression of atrichoblast-specific genes and thus specification of the non-hair fate (Masucci and Schiefelbein, 1996; 
Bruex et al., 2012). Further, a recent study showed that GL2 negatively regulates not only RHD6 but also other root-hair promoting bHLH genes, RHD6-LIKE1 (RSL1), RSL2, Lj-RHL1LIKE1 (LRL1), and LRL2, by binding to their upstream regions (Lin et al., 2015). In $\mathrm{H}$ cells, CPC inactivates the inhibitory pathway through negative regulation of GL2 expression (Lee and Schiefelbein, 2002; Wada et al., 2002), and thus promotes expression of GL2 target genes and consequently root hair cell differentiation.

Additionally, in atrichoblast cells, the WER/GL3/EGL3/TTG1 complex positively regulates $\mathrm{CPC}$ and two other root hair fate-promoting transcription factors, TRIPTYCHON (TRY) and ENHANCER OF TRY AND CPC1 (ETC1) (Lee and Schiefelbein, 2002; Wada et al., 2002; Bernhardt et al., 2003; Kirik et al., 2004; Koshino-Kimura et al., 2005; Ryu et al., 2005; Simon et al., 2007). The latter is also dependent on HDA6-mediated histone deacethylation for transcriptional regulation (Li et al., 2015). For many years, the WER/GL3/EGL3/TTG1 has been proposed as the main regulatory complex of cell-fate determination. In trichomes, however, besides the well-known GL1/GL3/TTG1 trimeric complex, GL3/TTG1 and GL3/GL1 form separate dimeric complexes that differentially regulate downstream genes (Pesch et al., 2015). As such, TRY is activated by GL3/TTG1, which is counteracted by GL1. CPC is activated by GL1/GL3, which is inhibited by TTG1. The question arises if this process of alternative complex formation is also present in root hair development? Can WER for instance form a complex with GL3, activating CPC? Or does WER counteract TRY activation by GL3/TTG1?

The current understanding is that, upon activation by the WER/GL3/EGL3/TTG1 complex, CPC, TRY, and ETC1 migrate to the adjacent root hair cells and competitively inhibit binding of WER to GL3/EGL3 (Lee and Schiefelbein, 2002; Kurata et al., 2005; Kang et al., 2013), which represents a lateral inhibition mechanism (LIM; Schiefelbein et al., 2014). In addition, TRY positively regulates the expression of the leucine rich repeat receptor-like kinase SCRAMBLED (SCM; Kwak and Schiefelbein, 2014), which is thought to mediate the positional signaling between the epidermis and the cortex through negative regulation of WER transcription (Kwak and Schiefelbein, 2007). SCM is part of an autoregulatory feedback loop, where its preferential accumulation in $\mathrm{H}$-cells is positively regulated by the downstream transcription factor TRY (in H-cells), and negatively regulated by the transcriptional WER/GL3/EGL3/TTG1 complex (in N-cells; Kwak and Schiefelbein, 2008). Interestingly, the kinase domain of SCM is enzymatically inactive (Chevalier et al., 2005); however, it is required for establishment of proper root hair patterning (Kwak et al., 2014). Until now, the ligand(s) of SCM remain unknown but potential downstream targets have been identified (Fulton et al., 2009; Bai et al., 2013; Trehin et al., 2013). Moreover, a zinc-finger protein called JACKDAW (JKD) has been proposed as being an upstream component of the SCM-dependent root hair regulatory network (Hassan et al., 2010).

This description demonstrates that the network of root epidermal cell patterning is highly complex and employs, besides regulatory mechanisms such as lateral inhibition, several feedback loops and interactions (reviewed in Schiefelbein et al., 2014).

Besides the abovementioned complex genetic cascades, also hormones, in particular ethylene, auxin and brassinosteroids (BRs), influence root epidermal cell fate determination. Pharmacological studies have shown that treatment with aminoethoxyvinylglycine (AVG), an ethylene biosynthesis inhibitor, or $\mathrm{Ag}^{+}$, an ethylene action inhibitor, abolishes root hair formation (Masucci and Schiefelbein, 1994; Tanimoto et al., 1995). Alternatively, increasing concentrations of 1aminocyclopropane-1-carboxylic acid (ACC), a precursor of ethylene, lead to progressively more ectopic root hairs (Tanimoto et al., 1995). In addition, the recessive mutation in CONSTITUTIVE TRIPLE RESPONSE1 (CTR1), which encodes a Raf-like protein kinase that negatively regulates ethylene signaling (Kieber et al., 1993) by binding to the ethylene receptor ETR1 (Huang et al., 2003), causes development of ectopic root hairs (Dolan et al., 1994). In contrast to ethylene, application of exogenous auxins, indole-3-acetic acid (IAA), and 2,4-Dichlorophenoxyacetic acid (2,4-D), seems to have no effect on epidermal cell fate determination as no ectopic root hairs are formed (Masucci and Schiefelbein, 1996; Pitts et al., 1998) even though auxin stimulates ethylene production in roots (Abeles et al., 1992). On the other hand, both ACC and IAA are able to restore root hair formation in the root hairless rhd6 mutant plants. Transcriptome analysis has shown that auxin and ethylene have an overlapping effect on the majority of RHD6-regulated genes, most likely due to linkage between their biosynthetic pathways (Bruex et al., 2012). RHD6 itself has, however, long been thought to function upstream of auxin signaling, and as such, the role of auxin in epidermal patterning has remained largely uncharacterized. Recently, Yi et al. (2010) showed that IAA-mediated reversion of the rhd6 phenotype is due to activation of the bHLH transcription factor ROOT HAIR DEFECTIVE 6-LIKE 4 (RSL4). RHD6 directly targets RSL4, which is now thought to form the first auxin-responsive component in the root hair signaling pathway. RSL4 protein starts accumulating $2 \mathrm{~h}$ before root hair initiation and reaches a maximum during the early stages of root hair development, after which it is slowly degraded by the $26 \mathrm{~S}$ proteasome during tip growth (Datta et al., 2015). Not only does RNAi-mediated silencing of RSL4 result in shorter root hairs, it also results in less root hairs per cell file. In addition, RSL2, the closest relative to RSL4, is also regulated by RHD6 and auxin, and the rsl2-1 rsl4-1 double loss-of-function mutant is hairless (Yi et al., 2010). Based on these findings we can conclude that it would be worthwhile to further investigate the role of RSL4 and RSL2 in root hair initiation.

Hormone or hormone-inhibitor treatments often lead to root hairless or ectopic root hair phenotypes. In addition, interference with normal auxin signaling also results in strongly reduced root hair formation. For instance, stabilized dominant AUX/IAA proteins (and corresponding mutants, e.g., axr2 and axr3) do not form root hairs (Wilson et al., 1990; Leyser et al., 1996; Knox et al., 2003). Curiously, however, no cell fate determination genes upstream of RSL4 have yet been shown to be direct targets of auxin or ethylene signaling. For sure, GL2 expression is 
not regulated by auxin or ethylene (Masucci and Schiefelbein, 1996). Using databases such as the PLACE database (Higo et al., 1999) a search for auxin (ARFAT; Ulmasov et al., 1995) and ethylene (ERELEE4 and GCC-box; Ohme-Takagi and Shinshi, 1990; Itzhaki et al., 1994) response elements in the promotor regions of early root hair cell fate determination genes could be conducted. The conserved ARFAT sequence (TGTCTC) is known to be a specific target for auxin-response factors (ARFs; Ulmasov et al., 1995, 1997, 1999a,b), which regulate auxin-mediated transcription after being derepressed through removal of the inhibiting interacting Aux/IAA proteins (reviewed in Rogg and Bartel, 2001). This analysis could enlighten the potentially heavily underestimated role of auxin- and ethylenesignaling in epidermal cell fate determination. In addition, an in detail analysis of the temporal transcriptional response of these genes to auxin is still lacking, but could provide valuable information.

For long, BRs have been considered to take part in regulating root hair tip growth, rather than in the preceding root epidermal cell fate determination (Kim et al., 2006). However, recent publications have shown otherwise (Kuppusamy et al., 2009; Cheng et al., 2014). Treatment of roots with brassinolide was shown to induce transcription of WER and its downstream target GL2 (Kuppusamy et al., 2009). Contrastingly, Kuppusamy et al. (2009) found no effect on the spatial distribution of GL2 transcription upon application of exogenous epibrassinolide, but Cheng et al. (2014) reported ectopic GL2 expression in H-cells in plants overexpressing the BR-receptor BRASSINOSTEROID INSENSITIVE (BRI1). Strikingly, however, Kuppusamy et al. (2009) showed that the bri1-mutant and brassinazole (BR biosynthetic inhibitor) treated plants had reduced WER and GL2 transcription, showed aberrant patterning of WER and GL2 expression in the epidermis, and that they contained an increase of non-hair cells in the H-position. The ectopic expression of WER and GL2 in bri1 roots was shown to be due to decreased expression of CPC (Kuppusamy et al., 2009). A model was proposed where BR-activated BRI1 induces WER expression in future $\mathrm{N}$-cells, resulting in CPC accumulation. Intercellular CPC translocation would inhibit WER and GL2 transcription in neighboring cells, and subsequently promote SCM accumulation. SCM in turn further represses WER transcription and promotes the $\mathrm{H}$-cell fate. As such, positional information for root epidermal cells is conveyed through both BRI1 and SCM (Kwak and Schiefelbein, 2007; Kuppusamy et al., 2009).

The consensus states that brassinosteroids are perceived at the plasma membrane localized BRI1 receptor (Li and Chory, 1997). BRI1-induced signal transduction in turn leads to inactivation of BRASSINOSTEROID INSENSITIVE 2 (BIN2), a GSK3-like kinase which, in its inactive form, accumulates in the nucleus to regulate gene transcription (Yang et al., 2011). Interestingly, Cheng et al. (2014) showed that BIN2 also directly binds to WER, EGL3, and TTG1 and phosphorylates the latter two. TTG1 phosphorylation inhibits WER/GL3/EGL3/TTG1 complex activity and subsequently GL2 transcription, whereas phosphorylation of EGL3 (which is transcribed in H-cells only) was shown to be responsible for both intra- and intercellular $(\mathrm{H}$ - to N-cells) EGL3 transport together with GL3 (Bernhardt et al., 2005; Cheng et al., 2014).

It is now clear that BRs are important components of the epidermal cell fate determination pathway, where they promote the $\mathrm{N}$-cell fate in the root epidermis. However, more evidence is needed to include these findings in the model of cell fate determination, especially regarding the spatial and temporal dynamics of BR perception and sensitivity, and subsequent cellspecific signal transduction. Is the sensitivity to BRs different in $\mathrm{H}$ - and N-cells? BRI1 is known to be ubiquitously expressed in the root (Friedrichsen et al., 2000), but artificial constriction of BRI1 expression in either $\mathrm{N}$ - or $\mathrm{H}$-cells differentially affects root cell elongation (Fridman et al., 2014). Curiously, no data is available comparing BRI1 density at the plasma membrane in $\mathrm{N}$ - and $\mathrm{H}$-cells. As such, a detailed spatial and temporal characterization of BRI1 and its downstream targets in Arabidopsis roots could provide useful insights.

\section{SWITCHING FROM DIFFUSE TO POLAR GROWTH AT A SPECIFIC SITE OF THE TRICHOBLAST}

The decision to initiate a root hair is made by the abovementioned mechanism(s) and promotes local cell wall outgrowths. But, how does a cell wall that has just adapted the architecture to prevent expansion at the end of the elongation zone, accommodate polar expansion (Figure 3)?

In Arabidopsis, root hair initiation begins with the establishment of polarity within epidermal cells and subsequent selection of the initiation site at the more basal part of the trichoblast (Carol and Dolan, 2002). Before a root hair emerges, plant RHO GTPase (RAC/ROP) proteins become polarly localized in the plasma membrane at the future growth site. These small GTPases remain present in the apical part of root hair bulges and at root hair tips until final cessation of growth, indicating that they are required for polar growth (Molendijk et al., 2001; Jones et al., 2002). This is further strengthened by the finding that mutations in ROP-interacting proteins, such as RHOGDI1/SCN1, result in a mis-localization of ROPs or in the appearance of additional ROP-spots on trichoblasts, which in turn results in altered or additional root hair initiation sites (Carol et al., 2005). In addition to polar ROP accumulation, the cell wall acidifies very locally at the site of future root hair bulge formation, whereas the cytosol becomes more alkaline. Rising external $\mathrm{pH}$ with buffers reversibly stops the bulge initiation process and indicates that wall acidification plays a role in the activation of cell wall loosening proteins, like expansins (Bibikova et al., 1998; Cho and Cosgrove, 2002) and xyloglucan endotransglucosylase/hydrolases (XTHs; Vissenberg et al., 2001), whose role is to re-loosen walls that just adopted an architecture to prevent further expansion. Although no loss-offunction mutants in XTH or expansin with root hair defects are described, the involvement of both proteins remains an attractive hypothesis. The expression of two Arabidopsis expansin genes (AtEXP7 and AtEXP18) is tightly linked to the early events of root hair formation and occurs before the cell wall bulges out 


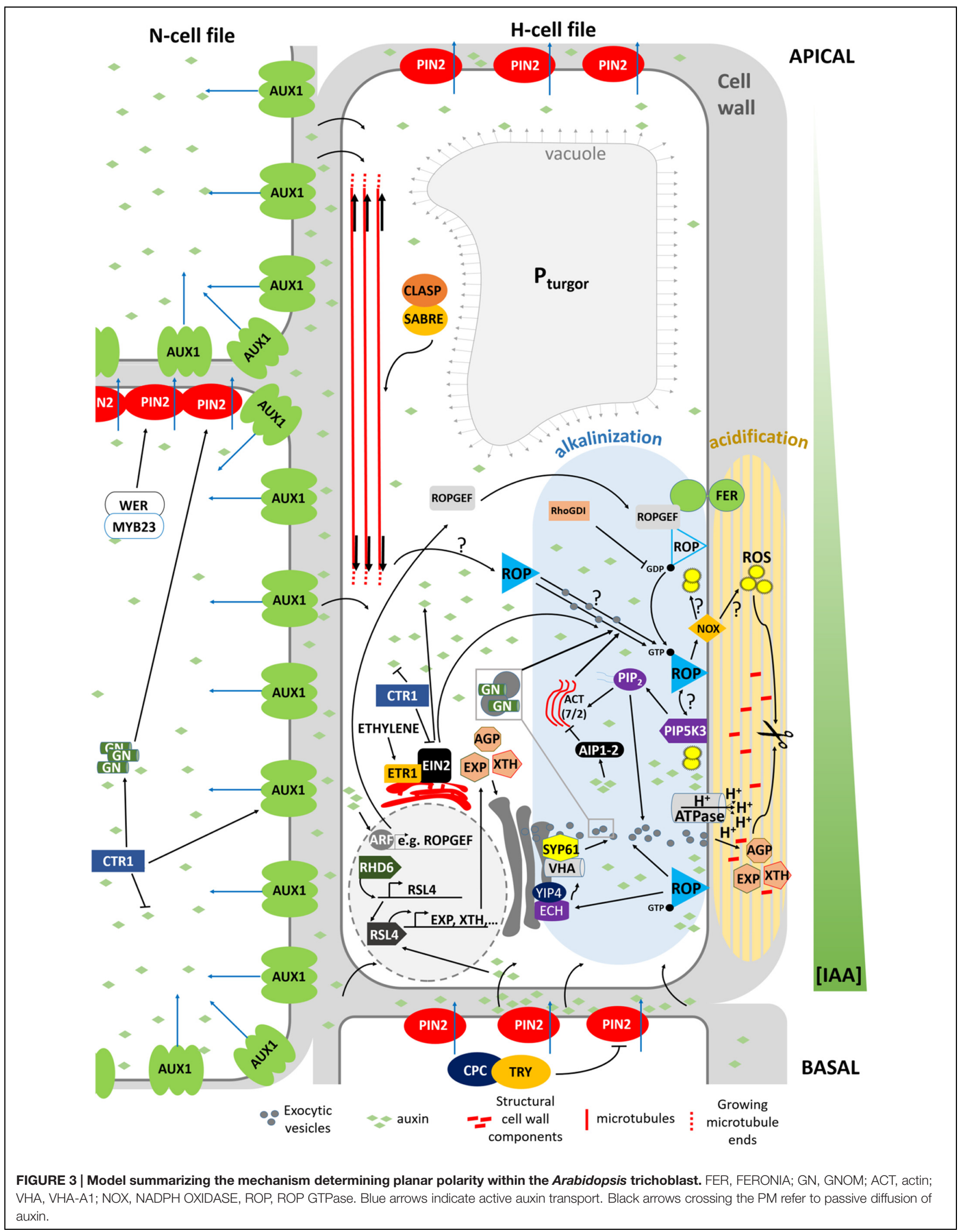


(Cho and Cosgrove, 2002). The auxin-inducible EXPA7 is one of 83 genes regulated by RSL4, thereby strengthening the hypothesis that RSL4 could be a direct transcriptional regulator of root epidermal bulge formation (Yi et al., 2010). The role of expansins in root hair initiation is substantiated in Maize and Barley (Baluška et al., 2000; Kwasniewski and Szarejko, 2006). Similarly, the very localized endo-transglucosylase (XET) activity of XTH proteins occurs before visible bulge formation (Vissenberg et al., 2001). The fact that localized cell wall loosening is one of the key factors in the bulge formation is strengthened by the finding that in rhd6 mutants crossed with prc1-1 (mutated in the cellulose synthase CESA6 gene resulting in reduced apoplastic cellulose; Fagard et al., 2000) the requirement for RHD6 during hair initiation is reduced. This might result from a weaker cell wall structure, due to the reduced cellulose content, which mimicks the effect of the cell wall loosening events by expansin and XTHs during the early stages of hair formation (Singh et al., 2008). Besides site-specific loosening of trichoblast cell walls, local wall compositional changes may aid normal expansion, as evidenced by the root epidermal bulger (reb1/rhd1) mutant that contains abnormally expanding trichoblast cells (Baskin et al., 1992), accompanied with changes in arabinogalactan (AGP) protein content in the walls (Andème-Onzighi et al., 2002). This all suggests that the bulge formation itself is mostly the result of local cell wall loosening and turgor-driven expansion of this apoplast site.

Which mechanisms then determine the exact site of apoplastic acidification and cell wall loosening? Evidence comes from axr21 and rhd6-mutants that exhibit hairs at a more shootward position of trichoblasts, and the mislocation of root hairs in the rhd6 mutant can be rescued by either auxin or addition of an ethylene precursor (Masucci and Schiefelbein, 1994). The involvement of both hormones in site determination is further supported by mislocated hairs on the etr and eto ethylene mutants (Masucci and Schiefelbein, 1996). In addition, mutant analysis reveals that auxin may provide positional information for ROP positioning at least through activity of AUX1, EIN2, and GNOM (Fischer et al., 2006) so that hairs are formed at this site of the cell where an auxin maximum can be found (Sabatini et al., 1999; Grebe et al., 2002; Ikeda et al., 2009). So how are these auxin gradients formed, and what is their role in the establishment of planar polarity? Recent findings point toward an elegant interplay between localized regulation of auxin biosynthesis, and differential distribution of auxin in- and efflux carriers in $\mathrm{N}$ - and $\mathrm{H}$-cells (Figure 4; Ikeda et al., 2009; Jones et al., 2009; Löfke et al., 2015). CTR1, which was previously highlighted for its role in cell-fate determination, also appears to function as a key regulator of auxin-induced planar polarity in root hair initiation (Ikeda et al., 2009). CTR1 inhibits auxin biosynthesis in a concentration-dependent manner through negative regulation of WEI2, WEI7 (key genes involved in auxin biosynthesis) and EIN2. Moreover, it is needed for uniform AUX1 localization to the plasma membrane of $\mathrm{N}$-cells and, through positive regulation of GNOM, for PIN2 localization to the apical membrane of $\mathrm{N}$ - and (to a lesser extent) $\mathrm{H}$-cells. The result is a long distance auxin gradient originating in the root tip
(Ikeda et al., 2009), and intracellular auxin gradients in N-cells (high auxin concentration) and $\mathrm{H}$-cells (10-fold lower auxin concentration; Jones et al., 2009). Interestingly, differential AUX1 and PIN2 accumulation/localization in N-cells (uniform AUX1 distribution and high PIN2 abundance) and H-cells (no AUX1 and 30\% lower PIN2 abundance) is at least in part dependent on early cell fate determination genes (Löfke et al., 2015). In N-cells, WER/MYB23 negatively regulate PIN2 turnover, whereas in H-cells, CPC/TRY positively affect PIN2 turnover and vacuolar degradation rates. How these gradients relate to localized accumulation of ROP GTPases at the future hair site remains elusive. The link between auxin concentration and bulge site determination was described in a mathematical model that can predict localized patches of active ROPs with the assumption that ROP activity is dependent on auxin concentration (Payne and Grierson, 2009). An auxin sensing system was proposed to control ROP GTPase during cell expansion in Arabidopsis leaves, making that the assumption will be close to reality (Chen and Yang, 2014). Although the appearance of the F-actin cytoskeleton was not significantly different in the basal region of trichoblasts when compared with the apical ends of the same cells (Kiefer et al., 2014) and although prevention of targeted vesicle delivery by disrupting the F-actin cytoskeleton did not affect the bulge formation (Čiamporová et al., 2002), Kiefer et al. (2014) nevertheless provide evidence for the requirement of ACTIN7 (ACT7) interaction with the negative modulator ACTIN-INTERACTING PROTEIN12 (AIP1-2) during polar ROP placement. Furthermore, AIP12 expression is enriched in hair cell files, it is under control of WER and is sensitive to ethylene and auxin treatment, which makes it a modulator of auxin-gradient dependent cell polarization by ACT7. Exactly how ROP placement is achieved by ACT7 and AIP1-2 remains unclear, since early polar ROP localisation is not affected by short-term F-actin destabilization (Molendijk et al., 2001), suggesting that it happens in an indirect manner. Because Brefeldin A (BFA) inhibits the enzyme activity of Arabidopsis GNOM Arf GDP/GTP exchange factors (GEF) that control cycling between GTPbound (on) and GDP-bound (off) states of ROPs and the early localization of ROP at the plasmamembrane of the future initiation site (Molendijk et al., 2001), it is possible that root hair initiation begins with an Arf-dependent, actinindependent vesicle trafficking, such as secretion at an internal cue, and is then followed by polar localization of ROP. Also the microtubular cytoskeleton helps to define the root hair initiation site. A reoriented, bipolar arrangement of longitudinally growing microtubules was detected in elongating trichoblasts just before they initiated a hair (Pietra et al., 2013). In these cells the majority of microtubule plus ends grew with apical directionality at apical ends of cells and with basal directionality at basal ends of cells, resembling what was described in elongating hypocotyl cells (Sambade et al., 2012). SABER and CLASP proteins interact and seem required to form this specific microtubular arragement, allowing correct root hair initation site determination (Pietra et al., 2013). How exactly microtubules mediate root hair initiation site determination remains unclear at the moment. 


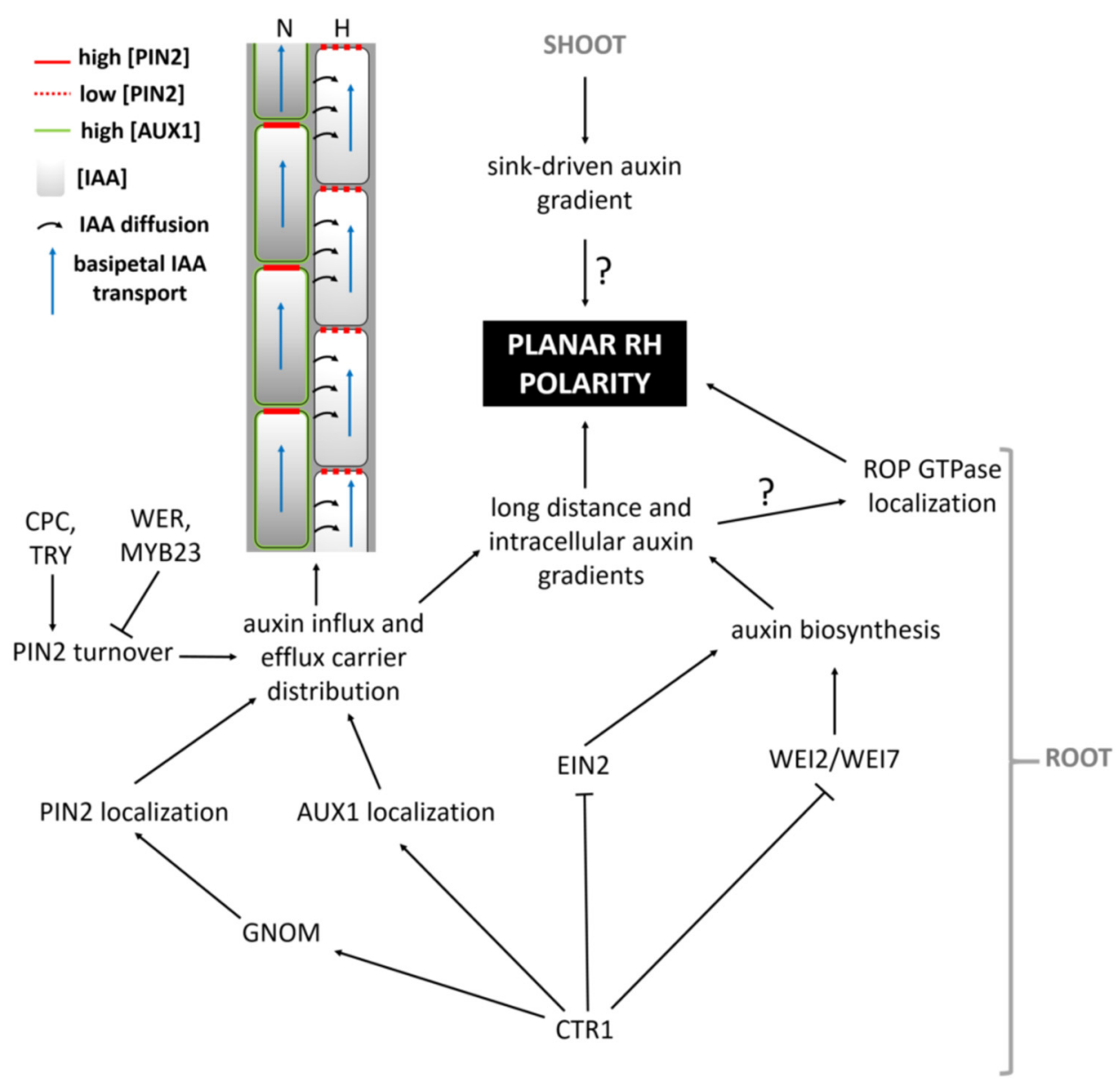

FIGURE 4 | Model summarizing the pathway leading up to the establishment of auxin-mediated planar polarity.

From the above, it seems ROP localisation and activity are the key determinants of root hair bulge site determination, but what are ROP's functions and what happens downstream of ROP activity? In general, Rho GTPases are molecular switches that control a wide variety of signal transduction pathways (Etienne-Manneville and Hall, 2002), and members of one clade, plant RAC/ROPs, play important roles in regulating cell growth and polarity establishment, responses toward hormones and stress, development, reproduction, and interactions with the environment (Nibau et al., 2006; Yang and $\mathrm{Fu}, 2007$; Kost, 2008). Compelling evidence suggests that for instance active ROP2 can activate NADPH-oxidases that produce ROS, which controls root hair development by altering the cell wall architecture, intracellular signaling and membrane trafficking (Foreman et al., 2003; Carol et al., 2005; Jones et al., 2007; Duan et al., 2010; Boisson-Dernier et al., 2013). Interestingly, the Receptor-Like Kinase (CrRLK) FERONIA (FER) was co-immunoprecipitated with ROP2 in a guanine nucleotide-regulated manner (Duan et al., 2010). Fer-mutants have collapsed, burst, to short root hairs, but unfortunately no information is available on the exact location of the root hairs on the individual cells (Duan et al.,
2010). Yet, the combination of ROP2 being polarly localized and the homogeneous presence of FER in epidermal cell membranes, provides the opportunity for localized ROP2-FER interaction and related downstream effects during root hair initiation site determination. This remains, however, to be proven.

Kusano et al. (2008) provide evidence that Phosphatidylinositol Phosphate 5-Kinase 3 (PIP5K3), a key enzyme for the production of Phosphatidylinositol 4,5bisphosphate [PtdIns $(4,5) \mathrm{P}_{2}$ ] (Oude Weernink et al., 2004), a well-studied signaling phospholipid, localizes not only to the elongating root hair apex, but also to the site of future root hair initiation. Since PIP5K3-YFP localized to growing root hairs before actual growth occurred and its fluorescence signal disappeared from the root hair tip before the root hairs elongation was complete, Kusano et al. (2008) conclude that PIP5K3 is one of the factors leading to cell expansion rather than being a result of cell expansion. The strongly reminiscent localization of ROP and PIP5K3 during root hair initiation and growth might reflect the recruitment and/or regulation of PIP5K3 by ROPs. It has been described before that the product of PIP5K3 activity, $\operatorname{PtdIns}(4,5) \mathrm{P}_{2}$, 


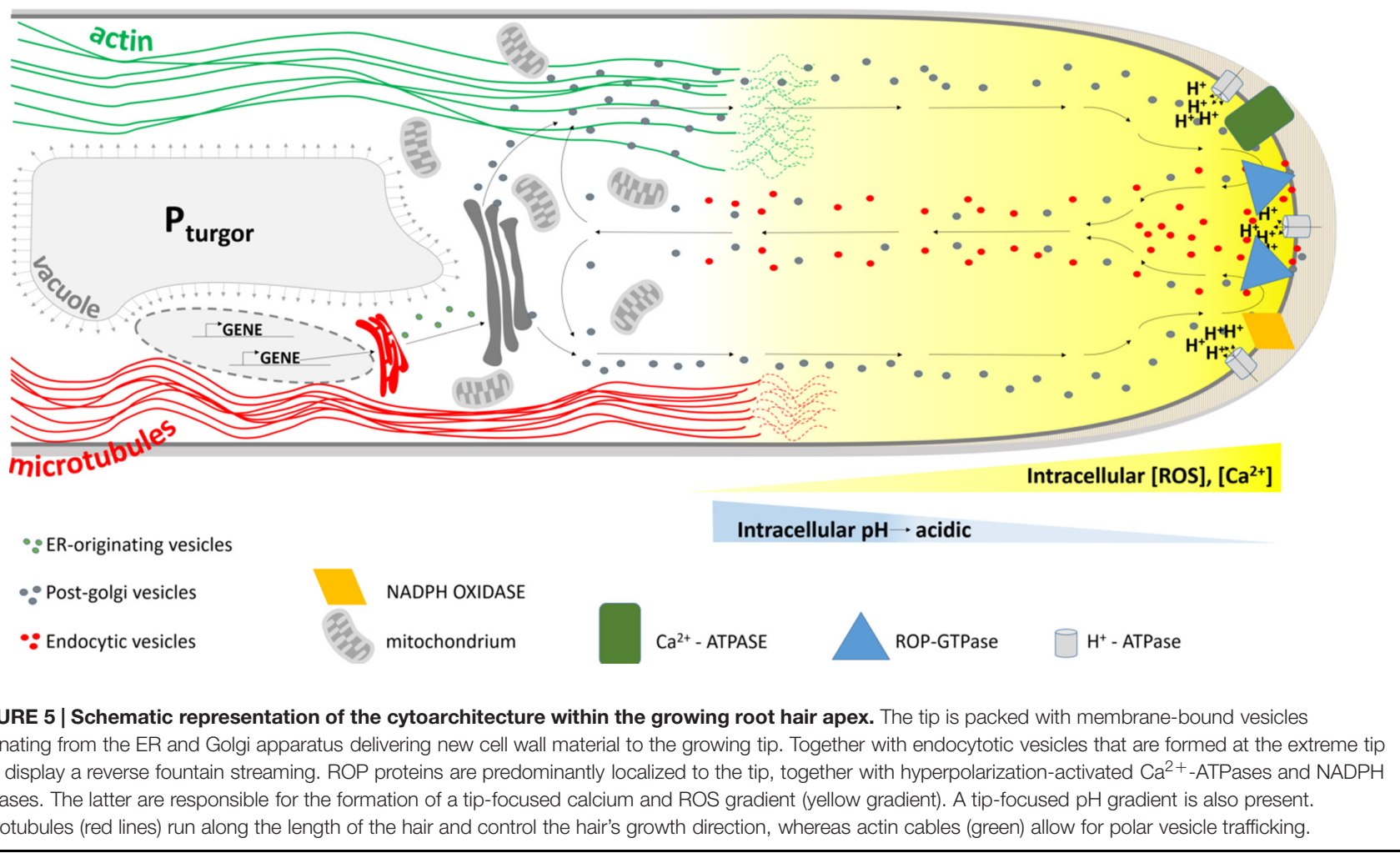

modulates the functions of a variety of actin regulatory proteins and regulators of the exocytotic machinery on the plasma membrane by directly interacting with its protein targets, and also acts as a substrate for the production of secondary messengers (see references in Kusano et al., 2008; Boss and Im, 2012; Krishnamoorthy et al., 2014). Localized secretion of cell wall modifying enzymes, cell wall components or proton-ATPases could then locally acidify the apoplast, since this acidification may be due to local changes in ionic (polymer) composition of the apoplast, or to ATP-driven outward pumping of protons across an intact plasmamembrane (Bibikova et al., 1998). One line of evidence could be given by the echidna and yip mutants (Gendre et al., 2011, 2013; Boutté et al., 2013), which show impaired post-Golgi network trafficking if they fail to produce bulges. This, however, is not proven yet. In the echidna-mutant the localization of ROP proteins appears to be normal indicating that $\mathrm{ECH}$ acts downstream of ROP localization and suggesting that deposition of certain vesicle cargos are required for root hair bulge formation. Moreover, recently ECHIDNA was shown to regulate the secretion of cell wall polysaccharides through interaction with the YPT/RAB GTPase interacting proteins $4 \mathrm{a}$ and $4 \mathrm{~b}$ (YIP4a, YIP4b) and regulation of TGN components VHA-a1 and SYP61 (Gendre et al., 2013). A second and more direct line of evidence for localized secretion of certain components during root hair initiation is given by the tip-accumulation of RabAld, labeling trans-Golgi network vesicles, in the root hair bulges (Berson et al., 2014). Taken together, whether active ROP alone or in combination with
FER activates the formation of $\operatorname{ROS}$ and $\operatorname{PtdIns}(4,5) \mathrm{P}_{2}$ to start the apoplastic acidification and further wall loosening remains to be solved. The whole cascade is summarized in Figure 3.

\section{TIP GROWTH MAINTENANCE AND TERMINATION}

When the bulge is fully formed, the transition from initiation to tip growth begins with the accumulation of secretory vesicles at the apical part of the bulge. A tip growing root hair has a highly organized cytoarchitecture (Figure 5). The hemispherical apex is filled with densely packed vesicles while small organelles such as Golgi stacks, mitochondria, endoplasmic reticulum and plastids are present in a sub-apical region. The more basal part of a hair contains a large vacuole that occupies most of the space. The nucleus enters the hair and follows the growing tip at a constant distance. When a root hair becomes mature and growth ceases, this highly polar organization of the cytoplasm disappears (Ryan et al., 2001). Several players are known that mediate the tip growth of root hairs, but fall out of the scope of this review.

\section{CONCLUDING REMARKS}

Abundant genetic, molecular, and mutant resources have made that the Arabidopsis thaliana root is being successfully exploited as a model system to elucidate 
complex molecular pathways leading to cell fate determination, planar cell polarity, and tip growth. Many players in these pathways have been described. However, undoubtedly several are yet to be identified. The influence and action of phytohormones such as auxin, ethylene and brassinosteroids on root architecture and development is generally recognized, yet their roles in the different developmental processes are far from fully understood. Several open questions thus still remain, and answers are needed to understand the intriguing complexity of development on the single cell level.

\section{REFERENCES}

Abeles, F. B., Morgan, P. W., and Saltveit, M. E. Jr. (1992). Ethylene in Plant Biology. San Diego, CA: Academic Press.

Andème-Onzighi, C., Sivaguru, M., Judy-March, J., Baskin, T. I., and Driouich, A. (2002). The reb1-1 mutation of Arabidopsis alters the morphology of trichoblasts, the expression of arabinogalactan-proteins and the organization of cortical microtubules. Planta 215, 949-958. doi: 10.1007/s00425-002-0836-Z

Anderson, C. T., Carroll, A., Akhmetova, L., and Somerville, C. (2010). Real-time imaging of cellulose reorientation during cell wall expansion in Arabidopsis roots. Plant Physiol. 152, 787-796. doi: 10.1104/pp.109.150128

Bai, Y., Vaddepalli, P., Fulton, L., Bhasin, H., Hülskamp, M., and Schneitz, K. (2013). ANGUSTIFOLIA is a central component of tissue morphogenesis mediated by the atypical receptor-like kinase STRUBBELIG. BMC Plant Biol. 13:16. doi: 10.1186/1471-2229-13-16

Baluška, F., Salaj, J., Mathur, J., Braun, M., Jasper, F., Šamaj, J., et al. (2000). Root hair formation: F-actin-dependent tip growth is initiated by local assembly of profilin-supported F-actin meshworks accumulated within expansin-enriched bulges. Dev. Biol. 227, 618-632. doi: 10.1006/dbio.2000.9908

Baskin, T. I., Betzner, A. S., Hoggart, R., Cork, A., and Williamson, R. E. (1992). Root morphology mutants in Arabidopsis thaliana. Aust. J. Plant Physiol. 19, 427-437. doi: 10.1071/PP9920427

Berger, F., Hung, C. Y., Dolan, L., and Schiefelbein, J. (1998). Control of cell division in the root epidermis of Arabidopsis thaliana. Dev. Biol. 194, 235-245. doi: 10.1006/dbio.1997.8813

Bernhardt, C., Lee, M. M., Gonzalez, A., Zhang, F., Lloyd, A., and Schiefelbein, J. (2003). The bHLH genes GLABRA3 (GL3) and ENHANCER OF GLABRA3 (EGL3) specify epidermal cell fate in the Arabidopsis root. Development 130, 6431-6439. doi: 10.1242/dev.00880

Bernhardt, C., Zhao, M., Gonzalez, A., Lloyd, A., and Schiefelbein, J. (2005). The bHLH genes GL3 and EGL3 participate in an intercellular regulatory circuit that controls cell patterning in the Arabidopsis root epidermis. Development 132, 291-298. doi: 10.1242/dev.01565

Berson, T., von Wangenheim, D., Takáè, T., Šamajová, O., Rosero, A., Oveèka, M., et al. (2014). Trans-Golgi network localized small GTPase RabA1d is involved in cell plate formation and oscillatory root hair growth. BMC Plant Biol. 14:252. doi: 10.1186/s12870-014-0252-0

Bibikova, T. N., Jacob, T., Dahse, I., and Gilroy, S. (1998). Localized changes in apoplastic and cytoplasmic $\mathrm{pH}$ are associated with root hair development in Arabidopsis thaliana. Development 125, 2925-2934.

Boisson-Dernier, A., Lituiev, D. S., Nestorova, A., Franck, C. M., Thirugnanarajah, S., and Grossniklaus, U. (2013). ANXUR receptor-like kinases coordinate cell wall integrity with growth at the pollen tube tip via NADPH oxidases. PLoS Biol. 11:e1001719. doi: 10.1371/journal.pbio.1001719

Boss, W. F., and Im, Y. J. (2012). Phosphoinositide signaling. Annu. Rev. Plant Biol. 63, 409-429. doi: 10.1146/annurev-arplant-042110-103840

Boutté, Y., Jonsson, K., McFarlane, H. E., Johnson, E., Gendre, D., Swarup, R., et al. (2013). ECHIDNA-mediated post-golgi trafficking of auxin carriers for differential cell elongation. Proc. Natl. Acad. Sci. U.S.A. 110, 16259-16264. doi: 10.1073/pnas.1309057110

Bringmann, M., Landrein, B., Schudoma, C., Hamant, O., Hauser, M. T., and Persson, S. (2012a). Cracking the elusive alignment hypothesis: the

\section{AUTHOR CONTRIBUTIONS}

$\mathrm{DB}, \mathrm{SS}$, and KV studied the literature, critically reflected on the current knowledge and wrote the review.

\section{FUNDING}

The authors acknowledge the financial support by the University of Antwerp (BOF-NOI/LP/DOCPRO and BOF-DOCPRO4) and the Research Foundation Flanders (FWO Vlaanderen)

microtubule-cellulose synthase nexus unraveled. Trends Plant Sci. 17, 666-674. doi: 10.1016/j.tplants.2012.06.003

Bringmann, M., Li, E., Sampathkumar, A., Kocabek, T., Hauser, M.-T., and Persson, S. (2012b). POM-POM2/cellulose synthase interacting1 is essential for the functional association of cellulose synthase and microtubules in Arabidopsis. Plant Cell 24, 163-177. doi: 10.1105/tpc.111.093575

Bruex, A., Kainkaryam, R. M., Wieckowski, Y., Kang, Y. H., Bernhardt, C., Xia, Y., et al. (2012). A gene regulatory network for root epidermis cell differentiation in Arabidopsis. PLoS Genet. 8:e1002446. doi: 10.1371/journal.pgen.1002446

Carol, R. J., and Dolan, L. (2002). Building a hair: tip growth in Arabidopsis thaliana root hairs. Philos. Trans. R. Soc. B Biol. Sci. 357, 815-821. doi: 10.1098/rstb.2002.1092

Carol, R. J., Takeda, S., Linstead, P., Durrant, M. C., Kakesova, H., Derbyshire, P., et al. (2005). A RhoGDP dissociation inhibitor spatially regulates growth in root hair cells. Nature 438, 1013-1016. doi: 10.1038/nature04198

Chen, J., and Yang, Z. (2014). Novel ABP1-TMK auxin sensing system controls ROP GTPase- mediated interdigitated cell expansion in Arabidopsis. Small GTPases 5, e28711. doi: 10.4161/sgtp.29711

Cheng, Y., Zhu, W., Chen, Y., Ito, S., Asami, T., and Wang, X. (2014). Brassinosteroids control root epidermal cell fate via direct regulation of a MYB-bHLH-WD40 complex by GSk3-like kinases. Elife Sci. 3, e02525. doi: 10.7554/eLife.02525

Chevalier, D., Batoux, M., Fulton, L., Pfister, K., Yadav, R. K., Schellenberg, M., et al. (2005). STRUBBELIG defines a receptor kinase-mediated signaling pathway regulating organ development in Arabidopsis. Proc. Natl. Acad. Sci. U.S.A. 102, 9074-9079. doi: 10.1073/pnas.0503526102

Cho, H. T., and Cosgrove, D. J. (2002). Regulation of root hair initiation and expansin gene expression in Arabidopsis. Plant Cell 14, 3237-3253. doi: $10.1105 /$ tpc.006437

Čiamporová, M., Dekánková, K., Hanáčková, Z., Peters, P., Ovečka, M., and Baluška, F. (2003). Structural aspects of bulge formation during root hair initiation. Plant Soil 255, 1-7. doi: 10.1023/A:1026151000063

Cosgrove, D. J. (2000). Loosening of plant cell walls by expansins. Nature 407, 321-326. doi: 10.1038/35030000

Datta, S., Prescott, H., and Dolan, L. (2015). Intensity of a pulse of RSL4 transcription factor synthesis determines Arabidopsis root hair cell size. Nat. Plants 1, 15138. doi: 10.1038/NPLANTS.2015.138

Dolan, L., Duckett, C. M., Grierson, C., Linstead, P., and Schneider, K. (1994). Clonal relationships and cell patterning in the root epidermis of Arabidopsis. Development 120, 2465-2474.

Dolan, L., Janmaat, K., Willemsen, V., Linstead, P., Poethig, S., Roberts, K., et al. (1993). Cellular organisation of the Arabidopsis thaliana root. Development 119, 71-84.

Duan, Q., Kita, D., Li, C., Cheung, A. Y., and Wu, H. M. (2010). FERONIA receptor-like kinase regulates RHO GTPase signaling of root hair development. Proc. Natl. Acad. Sci. U.S.A. 107, 17821-17826. doi: 10.1073/pnas. 1005366107

Esch, J. J., Chen, M., Sanders, M., Hillestad, M., Ndkium, S., Idelkope, B., et al. (2003). A contradictory GLABRA3 allele helps define gene interactions controlling trichome development in Arabidopsis. Development 130, 58855894. doi: 10.1242/dev.00812

Etienne-Manneville, S., and Hall, A. (2002). Rho GTPases in cell biology. Nature 420, 629-635. doi: 10.1038/nature01148 
Fagard, M., Desnos, T., Desprez, T., Goubet, F., Refrégier, G., Mouille, G., et al. (2000). PROCUSTE1 encodes a cellulose synthase required for normal cell elongation specifically in roots and dark-grown hypocotyls of Arabidopsis. Plant Cell 12, 2409-2424. doi: 10.2307/3871238

Fischer, U., Ikeda, Y., Ljung, K., Serralbo, O., Singh, M., Heidstra, R., et al. (2006). Vectorial information for Arabidopsis planar polarity is mediated by combined AUX1, EIN2 and GNOM activity. Curr. Biol. 16, 2143-2149. doi: 10.1016/j.cub.2006.08.091

Foreman, J., Demidchik, V., Bothwell, J. H., Mylona, P., Miedema, H., Torres, M. A., et al. (2003). Reactive oxygen species produced by NADPH oxidase regulate plant cell growth. Nature 422, 442-446. doi: 10.1038/nature01485

Fridman, Y., Elkouby, L., Holland, N., Vragovic, K., Elbaum, R., and Savaldi-Goldstein, S. (2014). Root growth is modulated by differential hormonal sensitivity in neighboring cells. Genes Dev. 28, 912-920. doi: $10.1101 /$ gad.239335.114

Friedrichsen, D. M., Joazeiro, C. A., Li, J., Hunter, T., and Chory, J. (2000). Brassinosteroid-insensitive-1 is a ubiquitously expressed leucine-rich repeat receptor serine/threonine kinase. Plant Physiol. 123, 1247-1256. doi: 10.1104/pp.123.4.1247

Fulton, L., Batoux, M., Vaddepalli, P., Yadav, R. K., Busch, W., Andersen, S. U., et al. (2009). DETORQUEO, QUIRKY, and ZERZAUST represent novel components involved in organ development mediated by the receptor-like kinase STRUBBELIG in Arabidopsis thaliana. PLoS Genet. 5:e1000355. doi: 10.1371/journal.pgen.1000355

Galway, M. E., Masucci, J. D., Lloyd, A. M., Walbot, V., Davis, R. W., and Schiefelbein, J. W. (1994). The TTG gene is required to specify epidermal cell fate and cell patterning in the Arabidopsis root. Dev. Biol. 166, 740-754. doi: 10.1006/dbio.1994.1352

Gendre, D., McFarlane, H. E., Johnson, E., Mouille, G., Sjödin, A., Oh, J., et al. (2013). Trans-Golgi network localized ECHIDNA/Ypt interacting protein complex is required for the secretion of cell wall polysaccharides in Arabidopsis. Plant Cell 25, 2633-2646. doi: 10.1105/tpc.113.112482

Gendre, D., Oh, J., Boutté, Y., Best, J. G., Samuels, L., Nilsson, R., et al. (2011). Conserved Arabidopsis ECHIDNA protein mediates trans-Golginetwork trafficking and cell elongation. Proc. Natl. Acad. Sci. U.S.A. 108, 8048-8053. doi: 10.1073/pnas. 1018371108

Grebe, M., Friml, J., Swarup, R., Ljung, K., Sandberg, G., Terlou, M., et al. (2002). Cell polarity signaling in Arabidopsis involves a BFA-sensitive auxin influx pathway. Curr. Biol. 12, 329-334. doi: 10.1016/S0960-9822(02)00654-1

Hassan, H., Scheres, B., and Blilou, I. (2010). JACKDAW controls epidermal patterning in the Arabidopsis root meristem through a non-cell-autonomous mechanism. Development 137, 1523-1529. doi: 10.1242/dev.048777

Higo, K., Ugawa, Y., Iwamoto, M., and Korenaga, T. (1999). Plant cis-acting regulatory DNA elements (PLACE) database: 1999. Nucleic Acids Res. 27, 297-300. doi: 10.1093/nar/27.1.297

Huang, Y., Li, H., Hutchison, C. E., Laskey, J., and Kieber, J. J. (2003). Biochemical and functional analysis of CTR1, a protein kinase that negatively regulates ethylene signaling in Arabidopsis. Plant J. 33, 221-233. doi: 10.1046/j.1365313X.2003.01620.x

Ikeda, Y., Men, S., Fischer, U., Stepanova, A. N., Alonso, J. M., Ljung, K., et al. (2009). Local auxin biosynthesis modulates gradient-directed planar polarity in Arabidopsis. Nat. Cell Biol. 11, 731-738. doi: 10.1038/ncb1879

Itzhaki, H., Maxson, J. M., and Woodson, W. R. (1994). An ethylene-responsive enhancer element is involved in the senescence-related expression of the carnation glutathione-S-transferase (GST1) gene. Proc. Natl. Acad. Sci. U.S.A. 91, 8925-8929. doi: 10.1073/pnas.91.19.8925

Jones, A. R., Kramer, E. M., Knox, K., Swarup, R., Bennett, M. J., Lazarus, C. M., et al. (2009). Auxin transport through non-hair cells sustains root-hair development. Nat. Cell Biol. 11, 78-84. doi: 10.1038/ncb1815

Jones, M. A., Raymond, M. J., Yang, Z., and Smirnoff, N. (2007). NADPH oxidasedependent reactive oxygen species formation required for root hair growth depends on ROP GTPase. J. Exp. Bot. 58, 1261-1270. doi: 10.1093/jxb/erl279

Jones, M. A., Shen, J. J., Fu, Y., Li, L., Yang, Z., and Grierson, C. S. (2002). The Arabidopsis Rop2 GTPase is a positive regulator of both root-hair initiation and tip growth. Plant Cell 14, 763-776. doi: 10.1105/tpc.010359

Kang, Y. H., Song, S. K., Schiefelbein, J., and Lee, M. M. (2013). Nuclear trapping controls the position-dependent localization of CAPRICE in the root epidermis of Arabidopsis. Plant Physiol. 163, 193-204. doi: 10.1104/pp.113.221028
Keyes, S. D., Daly, K. R., Gostling, N. J., Jones, D. L., Talboys, P., Pinzer, B. R., et al. (2013). High resolution synchrotron imaging of wheat root hairs growing in soil and image based modelling of phosphate uptake. New Phytol. 198, 1023-1029. doi: $10.1111 /$ nph.12294

Kieber, J. J., Rothenberg, M., Roman, G., Feldmann, K. A., and Ecker, J. R. (1993). CTR1, a negative regulator of the ethylene response pathway in Arabidopsis, encodes a member of the raf family of protein kinases. Cell 72, 427-441. doi: 10.1016/0092-8674(93)90119-B

Kiefer, C. S., Claes, A. R., Nzayisenga, J.-C., Pietra, S., Stanislas, T., Hüser, A., et al. (2014). Arabidopsis AIP1-2 restricted by WER-mediated patterning modulates planar polarity. Development 142, 151-161. doi: 10.1242/dev.111013

Kim, H., Park, P. J., Hwang, H. J., Lee, S. Y., Oh, M. H., and Kim, S. G. (2006). Brassinosteroid signals control expression of the AXR3/IAA17 gene in the crosstalk point with auxin in root development. Biosci. Biotechnol. Biochem. 70, 768-773. doi: 10.1271/bbb.70.768

Kirik, V., Simon, M., Huelskamp, M., and Schiefelbein, J. (2004). The ENHANCER OF TRY AND CPC1 gene acts redundantly with TRIPTYCHON and CAPRICE in trichome and root hair cell patterning in Arabidopsis. Dev. Biol. 268, 506-513. doi: 10.1016/j.ydbio.2003.12.037

Knox, K., Grierson, C. S., and Leyser, O. (2003). AXR3 and SHY2 interact to regulate root hair development. Development 130, 5769-5777. doi: 10.1242/dev.00659

Koshino-Kimura, Y., Wada, T., Tachibana, T., Tsugeki, R., Ishiguro, S., and Okada, K. (2005). Regulation of CAPRICE transcription by MYB proteins for root epidermis differentiation in Arabidopsis. Plant Cell Physiol. 46, 817-826. doi: $10.1093 / \mathrm{pcp} / \mathrm{pci096}$

Kost, B. (2008). Spatial control of Rho (Rac-Rop) signaling in tip-growing plant cells. Trends Cell Biol. 18, 119-127. doi: 10.1016/j.tcb.2008.01.003

Krishnamoorthy, P., Sanchez-Rodriguez, C., Heilmann, I., and Persson, S. (2014). Regulatory roles of phosphoinositides in membrane trafficking and their potential impact on cell-wall synthesis and re-modelling. Ann. Bot. 114, 10491057. doi: 10.1093/aob/mcu055

Kuppusamy, K. T., Chen, A. Y., and Nemhauser, J. L. (2009). Steroids are required for epidermal cell fate establishment in Arabidopsis roots. Proc. Natl. Acad. Sci. U.S.A. 106, 8073-8076. doi: 10.1073/pnas.0811633106

Kurata, T., Ishida, T., Kawabata-Awai, C., Noguchi, M., Hattori, S., Sano, R., et al. (2005). Cell-to-cell movement of the CAPRICE protein in Arabidopsis root epidermal cell differentiation. Development 132, 5387-5398. doi: 10.1242/dev.02139

Kusano, H., Testerink, C., Vermeer, J. E., Tsuge, T., Shimada, H., Oka, A., et al. (2008). The Arabidopsis phosphatidylinositol phosphate 5-kinase PIP5K3 is a key regulator of root hair tip growth. Plant Cell 20, 367-380. doi: 10.1105/tpc.107.056119

Kwak, S. H., and Schiefelbein, J. (2007). The role of the SCRAMBLED receptor-like kinase in patterning the Arabidopsis root epidermis. Dev. Biol. 302, 118-131. doi: 10.1016/j.ydbio.2006.09.009

Kwak, S. H., and Schiefelbein, J. (2008). A feedback mechanism controlling SCRAMBLED receptor accumulation and cell-type pattern in Arabidopsis. Curr. Biol. 18, 1949-1954. doi: 10.1016/j.cub.2008.10.064

Kwak, S. H., and Schiefelbein, J. (2014). TRIPTYCHON, not CAPRICE, participates in feedback regulation of SCM expression in the Arabidopsis root epidermis. Plant Signal. Behav. 9, e973815. doi: 10.4161/15592324.2014. 973815

Kwak, S. H., Woo, S., Lee, M. M., and Schiefelbein, J. (2014). Distinct signaling mechanisms in multiple developmental pathways by the SCRAMBLED receptor of Arabidopsis. Plant Physiol. 166, 976-987. doi: $10.1104 /$ pp. 114.247288

Kwasniewski, M., and Szarejko, I. (2006). Molecular cloning and characterization of $\beta$-expansin gene related to root hair formation in barley. Plant Physiol. 141, 1149-1158. doi: 10.1104/pp.106.078626

Lee, M. M., and Schiefelbein, J. (1999). WEREWOLF, a MYB-related protein in Arabidopsis, is a position-dependent regulator of epidermal cell patterning. Cell 99, 473-483. doi: 10.1016/S0092-8674(00)81536-6

Lee, M. M., and Schiefelbein, J. (2002). Cell pattern in the Arabidopsis root epidermis determined by lateral inhibition with feedback. Plant Cell 14, 611618. doi: 10.1105/tpc.010434

Leyser, H. M., Pickett, F. B., Dharmasiri, S., and Estelle, M. (1996). Mutations in the AXR3 gene of Arabidopsis result in altered auxin response including 
ectopic expression from the SAUR-AC1 promoter. Plant J. 10, 403-413. doi: 10.1046/j.1365-313x.1996.10030403.x

Li, D. X., Chen, W. Q., Xu, Z. H., and Bai, S. N. (2015). HISTONE DEACETYLASE6-defective mutants show increased expression and acetylation of ENHANCER OF TRIPTYCHON AND CAPRICE1 and GLABRA2 with small but significant effects on root epidermis cellular pattern. Plant Physiol. 168, 1448-1458. doi: 10.1104/pp.15.00821

Li, J., and Chory, J. (1997). A putative leucine-rich repeat receptor kinase involved in brassinosteroid signal transduction. Cell 90, 929-938. doi: 10.1016/S00928674(00)80357-8

Lin, Q., Ohashi, Y., Kato, M., Tsuge, T., Gu, H., Qu, L. J., et al. (2015). GLABRA2 directly suppresses basic helix-loop-helix transcription factor genes with diverse functions in root hair development. Plant Cell 27, 2894-2906. doi: $10.1105 /$ tpc. 15.00607

Lin, Y., and Schiefelbein, J. (2001). Embryonic control of epidermal cell patterning in the root and hypocotyl of Arabidopsis. Development 128, 3697-3705.

Löfke, C., Scheuring, D., Dünser, K., Schöller, M., Luschnig, C., and Kleine-Vehn, J. (2015). Tricho- and atrichoblast cell files show distinct PIN2 auxin efflux carrier exploitations and are jointly required for defined auxin-dependent root organ growth. J. Exp. Bot. 66, 5103-5112. doi: 10.1093/jxb/erv282

Masucci, J. D., and Schiefelbein, J. W. (1994). The rhd6 mutation of Arabidopsis thaliana alters root-hair initiation through an auxin- and ethylene-associated process. Plant Physiol. 106, 1335-1346.

Masucci, J. D., and Schiefelbein, J. W. (1996). Hormones act downstream of TTG and GL2 to promote root hair outgrowth during epidermis development in the Arabidopsis root. Plant Cell 8, 1505-1517. doi: 10.1105/tpc.8. 9.1505

Menand, B., Yi, K., Jouannic, S., Hoffmann, L., Ryan, E., Linstead, P., et al. (2007). An ancient mechanism controls the development of cells with a rooting function in land plants. Science 316, 1477-1480. doi: 10.1126/science.1142618

Molendijk, A. J., Bischoff, F., Rajendrakumar, C. S. V., Friml, J., Braun, M., Gilroy, S., et al. (2001). Arabidopsis thaliana Rop GTPases are localized to tips of root hairs and control polar growth. EMBO J. 20, 2779-2788. doi: $10.1093 / \mathrm{emboj} / 20.11 .2779$

Nibau, C., Wu, H. M., and Cheung, A. Y. (2006). RAC/ROP GTPases: 'hubs' for signal integration and diversification in plants. Trends Plant Sci. 11, 309-315. doi: $10.1016 /$ j.tplants.2006.04.003

Ohme-Takagi, M., and Shinshi, H. (1990). Structure and expression of a tobacco $\beta$-1,3-glucanase gene. Plant Mol. Biol. 15, 941-946. doi: 10.1007/BF00039434

Oude Weernink, P. A., Schmidt, M., and Jakobs, K. H. (2004). Regulation and cellular roles of phosphoinositide 5-kinases. Eur. J. Pharmacol. 500, 87-99. doi: 10.1016/j.ejphar.2004.07.014

Paredez, A. R., Somerville, C. R., and Ehrhardt, D. W. (2006). Visualization of cellulose synthase demonstrates functional association with microtubules. Science 312, 1491-1495. doi: 10.1126/science.1126551

Payne, C. T., Zhang, F., and Lloyd, A. M. (2000). GL3 encodes a bHLH protein that regulates trichome development in Arabidopsis through interaction with GL1 and TTG1. Genetics 156, 1349-1362.

Payne, R. J. H., and Grierson, C. S. (2009). A theoretical model for ROP localisation by auxin in Arabidopsis root hair cells. PLOS One 4:e8337. doi: 10.1371/journal.pone.0008337

Pesch, M., Schultheiß, I., Klopffleisch, K., Uhrig, J. F., Koelg, M., Clemen, C. S., et al. (2015). TRANSPARANT TESTA GLABRA1 and GLABRA1 compete for binding to GLABRA3 in Arabidopsis. Plant Physiol. 168, 584-597. doi: 10.1104/pp.15.00328

Pietra, S., Gustavsson, A., Kiefer, C., Kalmbach, L., Hörstedt, P., Ikeda, I., et al. (2013). Arabidopsis SABRE and CLASP interact to stabilize cell division plane orientation and planar polarity. Nat. Commun. 4, 2779. doi: 10.1038/ncommns3779

Pitts, R. J., Cernac, A., and Estelle, M. (1998). Auxin and ethylene promote root hair elongation in Arabidopsis. Plant J. 16, 553-560. doi: 10.1046/j.1365313x.1998.00321.x

Rerie, W. G., Feldmann, K. A., and Marks, M. D. (1994). The GLABRA2 gene encodes a homeo domain protein required for normal trichome development in Arabidopsis. Genes Dev. 8, 1388-1399. doi: 10.1101/gad.8. 12.1388

Rogg, L. E., and Bartel, B. (2001). Auxin signaling: derepression through regulated proteolysis. Dev. Cell 1, 595-604. doi: 10.1016/S1534-5807(01)00077-6
Ryan, E., Steer, M., and Dolan, L. (2001). Cell biology and genetics of root hair formation in Arabidopsis thaliana. Protoplasma 215, 140-149. doi: 10.1007/BF01280310

Ryu, K. H., Kang, Y. H., Park, Y. H., Hwang, I., Schiefelbein, J., and Lee, M. M. (2005). The WEREWOLF MYB protein directly regulates CAPRICE transcription during cell fate specification in the Arabidopsis root epidermis. Development 132, 4765-4775. doi: 10.1242/dev.02055

Sabatini, S., Beis, D., Wolkenfelt, H., Murfett, J., Guilfoyle, T., Malamy, J., et al. (1999). An auxin-dependent distal organizer of pattern and polarity in the Arabidopsis root. Cell 99, 463-472. doi: 10.1016/S0092-8674(00)81535-4

Sambade, A., Pratap, A., Buschmann, H., Morris, R. J., and Lloyd, C. (2012). The influence of light on microtubule dynamics and alignment in the Arabidopsis hypocotyl. Plant Cell 24, 192-201. doi: 10.1105/tpc.111.093849

Schiefelbein, J., Huang, L., and Zheng, X. (2014). Regulation of epidermal cell fate in Arabidopsis roots: the importance of multiple feedback loops. Front. Plant Sci. 5:47. doi: 10.3389/fpls.2014.00047

Schiefelbein, J. W. (2000). Constructing a plant cell. the genetic control of root hair development. Plant Physiol. 124, 1525-1531. doi: 10.1104/pp.124.4.1525

Simon, M., Lee, M. M., Lin, Y., Gish, L., and Schiefelbein, J. (2007). Distinct and overlapping roles of single-repeat MYB genes in root epidermal patterning. Dev. Biol. 311, 566-578. doi: 10.1016/j.ydbio.2007.09.001

Singh, S. K., Fischer, U., Singh, M., Grebe, M., and Marchant, A. (2008). Insight into the early steps of root hair formation revealed by the procuste1 cellulose synthase mutant of Arabidopsis thaliana. BMC Plant Biol. 8:57. doi: 10.1186/1471-2229-8-57

Tanimoto, M., Roberts, K., and Dolan, L. (1995). Ethylene is a positive regulator of root hair development in Arabidopsis thaliana. Plant J. 8, 943-948. doi: 10.1046/j.1365-313X.1995.8060943.x

Trehin, C., Schrempp, S., Chauvet, A., Berne-Dedieu, A., Thierry, A. M., Faure, J. E., et al. (2013). QUIRKY interacts with STRUBBELIG and PAL OF QUIRKY to regulate cell growth anisotropy during Arabidopsis gynoecium development. Development 140, 4807-4817. doi: 10.1242/dev.091868

Ulmasov, T., Hagen, G., and Guilfoyle, T. J. (1997). ARF1, a transcription factor that binds to auxin response elements. Science 276, 1865-1868. doi: 10.1126/science. 276.5320 .1865

Ulmasov, T., Hagen, G., and Guilfoyle, T. J. (1999a). Activation and repression of transcription by auxin-response factors. Proc. Natl. Acad. Sci. U.S.A. 96, 5844-5849. doi: 10.1073/pnas.96.10.5844

Ulmasov, T., Hagen, G., and Guilfoyle, T. J. (1999b). Dimerization and DNA binding of auxin response factors. Plant J. 19, 309-319. doi: 10.1046/j.1365313X.1999.00538.x

Ulmasov, T., Liu, Z. B., Hagen, G., and Guilfoyle, T. J. (1995). Composite structure of auxin response elements. Plant Cell 7, 1611-1623. doi: 10.2307/ 3870023

Van Sandt, V. S. T., Suslov, D., Verbelen, J.-P., and Vissenberg, K. (2007). Xyloglucan endotransglucosylase activity loosens a plant cell wall. Ann. Bot. 100, 1467-1473. doi: $10.1093 / \mathrm{aob} / \mathrm{mcm} 248$

Verbelen, J.-P., De Cnodder, T., Le, J., Vissenberg, K., and Baluška, F. (2006). The root apex of Arabidopsis thaliana consists of four distinct zones of growth activities: meristematic zone, transition zone, fast elongation zone and growth terminating zone. Plant Signal. Behav. 1, 296-304. doi: 10.4161/psb.1. 6.3511

Vissenberg, K., Fry, S. C., and Verbelen, J.-P. (2001). Root hair initiation is coupled to a highly localized increase of xyloglucan endotransglycosylase action in Arabidopsis roots. Plant Physiol. 127, 1125-1135. doi: 10.1104/pp. 010295

Wada, T., Kurata, T., Tominaga, R., Koshino-Kimura, Y., Tachibana, T., Goto, K., et al. (2002). Role of a positive regulator of root hair development, CAPRICE, in Arabidopsis root epidermal cell differentiation. Development 129, 5409-5419. doi: $10.1242 /$ dev.00111

Wada, T., Tachibana, T., Shimura, Y., and Okada, K. (1997). Epidermal cell differentiation in Arabidopsis determined by a Myb homolog, CPC. Science 277, 1113-1116. doi: 10.1126/science.277.5329.1113

Walker, A. R., Davison, P. A., Bolognesi-Winfield, A. C., James, C. M., Srinivasan, N., Blundell, T. L., et al. (1999). The TRANSPARENT TESTA GLABRA1 locus, which regulates trichome differentiation and anthocyanin biosynthesis in Arabidopsis, encodes a WD40 repeat protein. Plant Cell 11, 1337-1349. doi: 10.1105/tpc.11.7.1337 
Wilson, A. K., Pickett, F. B., Turner, J. C., and Estelle, M. (1990). A dominant mutation in Arabidopsis confers resistance to auxin, ethylene and abscisic acid. Mol. Gen. Genet. 222, 377-383. doi: 10.1007/BF00633843

Wilson, M. H., Holman, T. J., Sørensen, I., Cancho-Sanchez, E., Wells, D. M., Swarup, R., et al. (2015). Multi-omics analysis identifies genes mediating the extension of cell walls in the Arabidopsis thaliana root elongation zone. Front. Cell Dev. Biol. 3:10. doi: 10.3389/fcell.2015.00010

Yang, C. J., Zhang, C., Lu, Y. N., Jin, J. Q., and Wang, X. L. (2011). The mechanisms of brassinosteroids' action: from signal transduction to plant development. Mol. Plant 4, 588-600. doi: 10.1093/mp/ssr020

Yang, Z., and Fu, Y. (2007). ROP/RAC GTPase signaling. Curr. Opin. Plant Biol. 10, 490-494. doi: 10.1016/j.pbi.2007.07.005

Yi, K., Menand, B., Bell, E., and Dolan, L. (2010). A basic helix-loop-helix transcription factor controls cell growth and size in root hairs. Nat. Genet. 42, 264-269. doi: 10.1038/ng.529
Zhang, F., Gonzalez, A., Zhao, M., Payne, C. T., and Lloyd, A. (2003). A network of redundant bHLH proteins functions in all TTG1-dependent pathways of Arabidopsis. Development 130, 4859-4869. doi: 10.1242/dev. 00681

Conflict of Interest Statement: The authors declare that the research was conducted in the absence of any commercial or financial relationships that could be construed as a potential conflict of interest.

Copyright (c) 2015 Balcerowicz, Schoenaers and Vissenberg. This is an open-access article distributed under the terms of the Creative Commons Attribution License (CC BY). The use, distribution or reproduction in other forums is permitted, provided the original author(s) or licensor are credited and that the original publication in this journal is cited, in accordance with accepted academic practice. No use, distribution or reproduction is permitted which does not comply with these terms. 